DOI https://doi.org/10.30525/978-9934-26-173-2-52

\title{
FEATURES OF USING INTERACTIVE POSTERS TO IMPROVE LEARNING EFFICIENCY
}

\author{
Yanovskyi A. O. \\ PhD in Pedagogical Science (Candidate of Pedagogical Sciences), \\ Associate Professor at the Department of Applied Mathematics \\ and Informatics \\ State Institution "South Ukrainian National Pedagogical University \\ named after K. D. Ushinsky" \\ Zykova N. $O$. \\ student of the department of technological and professional education \\ State Institution "South Ukrainian National Pedagogical University \\ named after K. D. Ushinsky" \\ Odessa, Ukraine
}

An interactive poster is a new type of electronic educational tool that provides a high level of involvement of information channels of perception of clarity in the educational process [2].

Interactivity refers to the interaction of the developed environment with the user.

The information world needs a constant search for new teaching aids that were effective and helped to increase the level of assimilation of new educational material by students and interested students, could increase their cognitive and stimulating mental activity. To implement the activity approach in modern education, the teacher needs to create new forms of organization of cognitive activity of students, namely self-educational activities with the discovery of new knowledge. These are active and interactive learning tools in which not only students and teachers interact, but also interactive learning tools that are prepared or selected by the teacher. And one of such means is becoming popular among modern information technologies - an interactive poster [2].

Thus, an interactive poster is a means of presenting information that is able to "cooperate" with the user for a fuller and deeper acquaintance with the material illustrated on the poster [7].

An interactive poster in the modern educational process gives the student the opportunity to better perceive certain educational material, because such posters are aimed at visualization and significantly increase interest in the 
topic and the educational material. Scientists have found a great way of presenting the material, students have the opportunity to repeat the material presented to them, because the interactive poster is easily embedded in a website or blog and the student can repeat the material presented by the teacher at any time. Posters, in addition, form students' skills of independent work, give the student the opportunity to see the result and evaluation of their work, the opportunity to find the right answer, to deepen their own knowledge [4].

The interactive poster has interactive navigation, which allows you to display the necessary information for students: graphics, text, video, audio, etc. [1].

The main function of an interactive poster is to provide a high level of visibility, and feedback, interaction [5].

Having studied some works of teachers, in particular practitioners, on the use of interactive posters in teaching students (L. Zheliznyak; I. Shakhina, O. Ilyina), taking into account their own practical and theoretical experience, we can identify its main features and functions, namely:

- dialogicity - interaction of teacher and students during the creation and presentation of the educational project using software applications (PowerPoint, Publisher, etc.) and online services (Glogster, etc.), which, in some way, motivates the teacher to use new methods and techniques of teaching students literature;

- easy to use - interactive poster does not require installation, has a simple and clear interface;

- rich visual material - eloquent animations of phenomena and processes, photographs and illustrations, which together give an advantage over other products and teaching aids;

- group and individual format of cooperation - allows you to organize work with the whole class with the involvement of an interactive whiteboard or demonstration screen, and with each student separately on a personal computer;

- educational material of programs is presented in the form of logically completed individual fragments, which allows the teacher to design lessons in accordance with the defined goal and objectives [3].

The following pedagogical goals can be achieved when creating interactive posters:

- support of group and individual forms of education in the classroom system of the educational process;

- creation of additional conditions for computer support of traditional and innovative learning technologies;

- increasing students' cognitive interest in the subject; 
- providing a differentiated approach to the study of the subject;

- structuring the content of education and activation of basic knowledge;

- opportunity to implement in practice a personality-oriented approach to learning;

- visualization of educational material [5].

There are many services that you can use to create interactive posters. We used Thinglink in our practice.

With this service, you can make special labels on a normal image, which when clicked display more information about the object [6].

Features of this service:

1. registration is required for work, there is a possibility of registration through the account in social networks;

2. works with all browsers, and also with iPad, iPhone and Android;

3. intuitive interface;

4. free use for 30 days;

5. free version allows you to place on an interactive image of up to 6 different elements [6].

We have created an interactive poster for a computer science lesson, for 5th grade students "Computer Structure". An interactive poster is a picture that shows tags that, when clicked, display the name of the object. If you click on the name of the object, a web page will automatically open, where students will be able to get acquainted in more detail with the object that interested them. The use of such interactive posters in computer science lessons promotes better learning by students, increases interest in the subject through interactivity. Interactive posters increase the efficiency of students' independent work, which affects the quality of formation of their practical skills and abilities. Posters encourage students to self-study sources of information and allow students to see the results and evaluate their own work. Interactive posters allow students to deepen their knowledge by searching for the correct answer and specific information.

\section{References:}

1. Belchev P. V. Interactive electronic poster as a modern didactic means of teaching physics in secondary school. Collection of scientific works of Berdyansk State Pedagogical University. (Pedagogical sciences). 2011. No. 2. P. 73-77. URL: https://virtkafedra.ucoz.ua/el_gurnal/pages/vyp14/ Tabler.pdf (date of access: 04.11.2021).

2. Idrisova A. A. Use of an interactive poster for development of active cognitive activity of the student. Economics and society. 2012. No. 2. P. 161-162. 
3. Ilyina O. I., Shakhina I. U. Interactive posters in educational activities. New pedagogical technologies as a response of higher school to the challenges of the innovative stage of world development. 2015. P. 404-405.

4. Ilyina O. I., Shakhina I. U. Interactive posters in educational activity. Collections of scientific works of NTU "KhPI": problems and prospects of formation of the national humanitarian and technical elite. 2015. 42- NTU "KhPI". URL: http://repository.kpi.kharkov.ua/handle/KhPIPress/15357 (date of access: 04.11.2021).

5. Interactive poster design technology. http://didaktor.ru/texnologiyakonstruirovaniya-interaktivnogo-plakatal.

6. Three convenient services for creating interactive images. https://vseosvita.ua/news/try-zruchni-servisy-dlia-stvorenniainteraktyvnykh-zobrazhen-6066.html.

7. Yurchenko A. O. Interactive poster as a means of presenting educational material. Scientific activity as a way of forming professional competencies of the future specialist: International scientific-practical conference "NPK - 2018", Sumy, 6 December 2018 - 7 December 2021. 2018. P. 98-100. 